\title{
Detection of S-100 labelled cells in nasopharyngeal carcinoma
}

\author{
LIBERO LAURIOLA, FABRIZIO MICHETTI, ${ }^{*}$ STENO SENTINELLI, DOMENICO \\ COCCHIA*
}

From the Departments of Human Pathology and *Anatomy, Universita Cattolica, Rome, Italy

SUMMARY S-100 antigen containing cells with dendritic features, recognisable by morphological and immunohistochemical criteria as belonging to the Langerhans' or interdigitating reticulum cell type, have been found in undifferentiated nasopharyngeal carcinoma. The presence of these cells, which have a special function of antigen presentation in immune responses, may be involved in a possible modulation of nasopharyngeal carcinoma associated Epstein-Barr virus infection and host-tumour interactions.

Nasopharyngeal carcinomas may be divided into two broad anatomo-clinical groups-undifferentiated nasopharyngeal carcinoma and squamous cell carcinoma-on the basis of morphological criteria and anti-Epstein-Barr virus serology. ${ }^{-4}$ The presence of Epstein-Barr virus antigens in neoplastic epithelial cells and the detection of high titres of antibodies to viral antigens in sera of patients suggest a causal relation between Epstein-Barr virus infection and undifferentiated nasopharyngeal carcinoma. $^{5}$ In this respect undifferentiated nasopharyngeal carcinoma, like Burkitt's lymphoma, represents an intriguing model in human pathology of the relation between viral infection, neoplastic transformation, and the immune response. The characteristics of the lymphocytic infiltrate in undifferentiated nasopharyngeal carcinoma have been investigated by several authors, ${ }^{6-8}$ but extensive investigation of the accompanying cells of mononuclear/phagocytic nature has not been undertaken. The recent finding of S-100 antigen in both epidermal Langerhans' cells and interdigitating reticulum cells of lymphoid organs $^{9}{ }^{10}$ led us to use S-100 immunolabelling as a tool for investigating the possible presence and distribution of Langerhans' and interdigitating reticulum cells in undifferentiated nasopharyngeal carcinoma. Immunohistochemical data are presented which show the presence of S-100 containing cells with dendritic morphology in undifferentiated nasopharyngeal carcinoma and in the lymph node metastases.

Accepted for publication 30 July 1984

\section{Material and methods}

Formalin fixed, paraffin embedded neoplastic tissue from 16 patients with carcinoma of the nasopharynx and from patients with squamous cell carcinoma of the oral cavity (two cases), larynx (two cases), and skin (four cases) were examined. Tissue slices were treated with $0.3 \%$ hydrogen peroxide in methanol for $20 \mathrm{~min}$ to block endogenous peroxidase activity and then processed for the immunoperoxidase reaction with the peroxidase-antiperoxidase method." Rabbit antiserum to S-100 either obtained commercially (Dakopatts a/s, Glostrup, Denmark) or produced by us as previously reported ${ }^{12}$ was used at dilutions varying from $1 / 500$ to $1 / 1000$. The specificity of the immunostaining was confirmed by replacing the primary antiserum with non-immune rabbit serum or preabsorption of anti-S-100 antiserum with purified antigen. Slices were also reacted with rabbit anti-human muramidase $(1 / 500)$ or antikeratin (1/400) antibodies (Dakopatts a/s, Glostrup, Denmark). The details of the immunostaining procedures have been reported elsewhere. ${ }^{12}$

\section{Results}

The 16 cases of nasopharyngeal carcinoma studied were classified by their prominent histological features according to Micheau $\mathrm{et}^{\mathrm{al}} \mathrm{l}^{3}$ : 10 were classified as undifferentiated nasopharyngeal carcinoma and six as squamous cell carcinoma. In eight of the 10 cases of undifferentiated nasopharyngeal carcinoma paraffin sections treated with anti-S-100 antiserum showed the presence of some labelled cells, which 


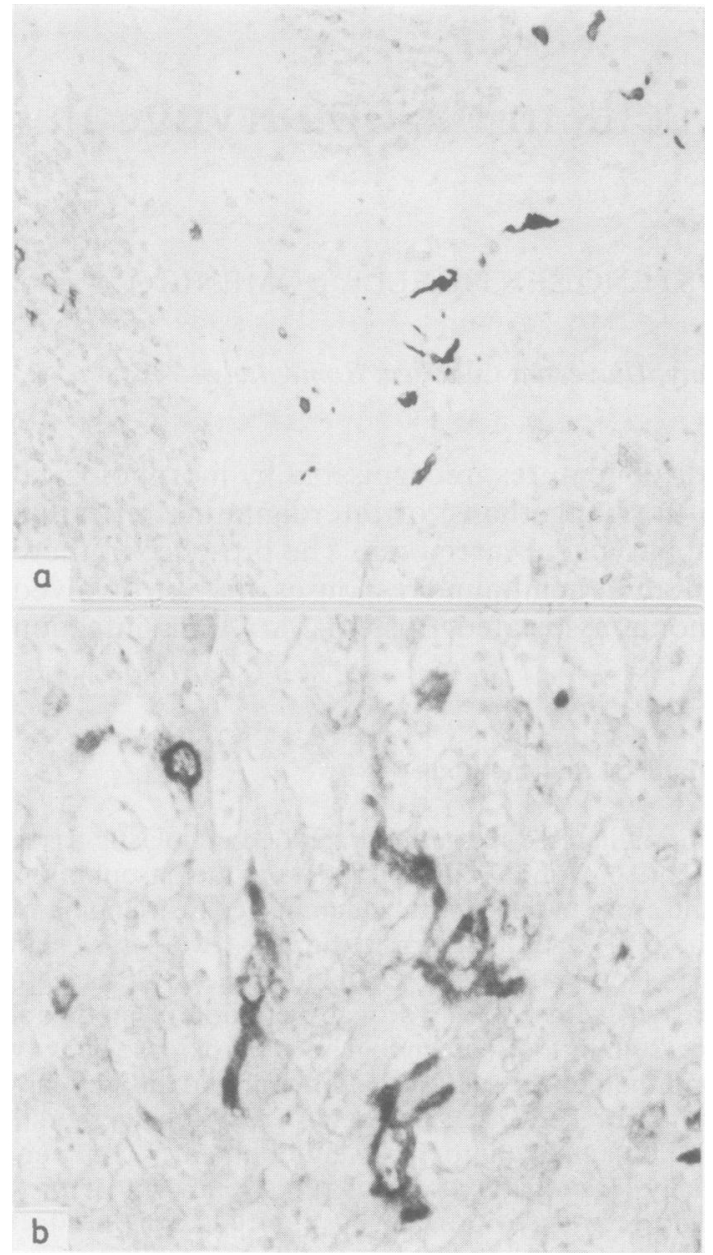

Fig. 1 Undifferentiated nasopharyngeal carcinoma treated with anti-S-100 antiserum. Haematoxylin counterstaining. (a) Immunostaining is confined to cells with elongated projections, irregularly distributed throughout the neoplastic epithelial cells. $\times 100$. (b) Higher magnification of immunolabelled cells exhibiting irregular profiles. $\times 400$.

were irregular in shape, often with dendritic features, and scattered throughout the neoplastic epithelial component (Figs. 1 and 2). In some cases the S-100-labelled cells were evenly distributed among the neoplastic epithelial cells while in other cases they were unevenly dispersed. When the anaplastic tumour cells formed well defined masses in the lymphatic stroma no preferential location of the labelled cells at the periphery or in the central area of the nest was seen. Moreover, in some cases S-100 labelled cells with dendritic morphology were present in the accompanying lymphoid infiltrate, although they were less abundant than in the neo-

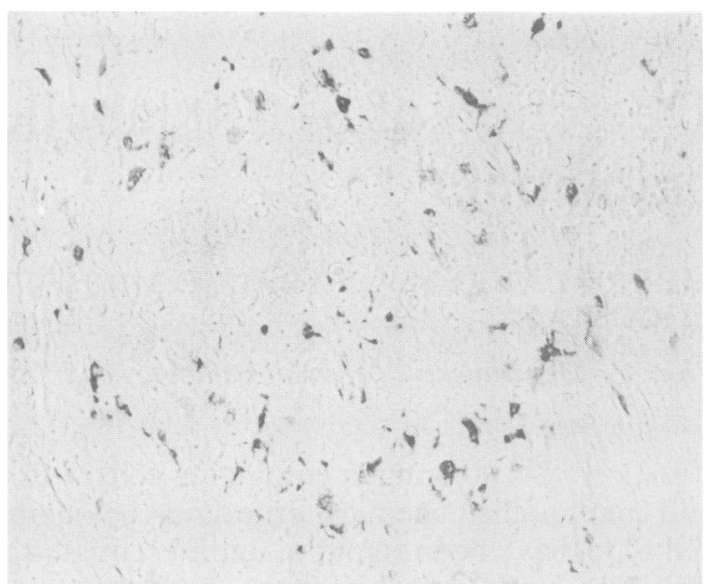

Fig. 2 Undifferentiated nasopharyngeal carcinoma treated with anti-S-100 antiserum. Immunoreaction product is confined to elongated dendritic cells scattered throughout the neoplastic tissue. $\times 100$.

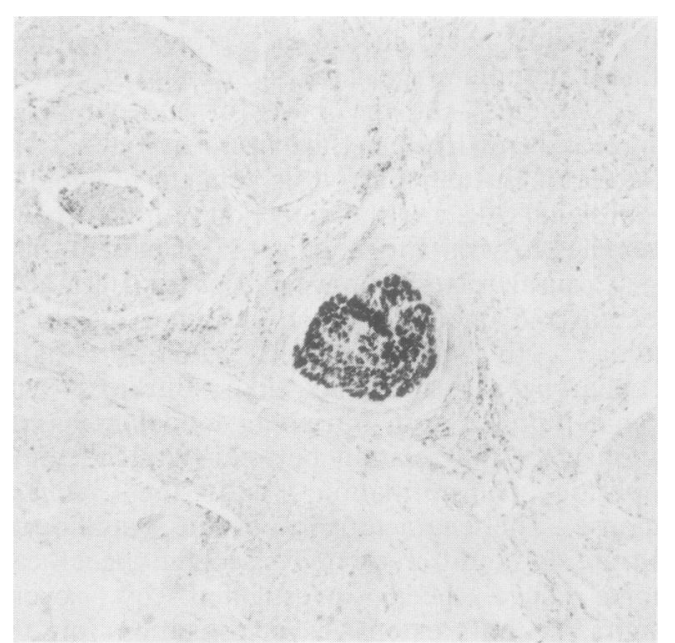

Fig. 3 Laryngeal carcinoma treated with anti-S-100 antiserum. Only a small nerve bundle appears to be stained by the immunoreaction product. $\times 60$.

plastic epithelium. In three cases, labelled cells with the same morphological features as those seen in undifferentiated nasopharyngeal carcinoma at the primary site were also detected among anaplastic epithelial cells that had metastasised to lymph nodes.

Only occasional S-100 positive cells were found in one of the six nasopharyngeal squamous cell carcinoma cases studied. Squamous cell carcinomas of mucosal or epidermal origin were also investigated by S-100 antiserum. Only one of the four cases of cutaneous origin showed an appreciable number of 


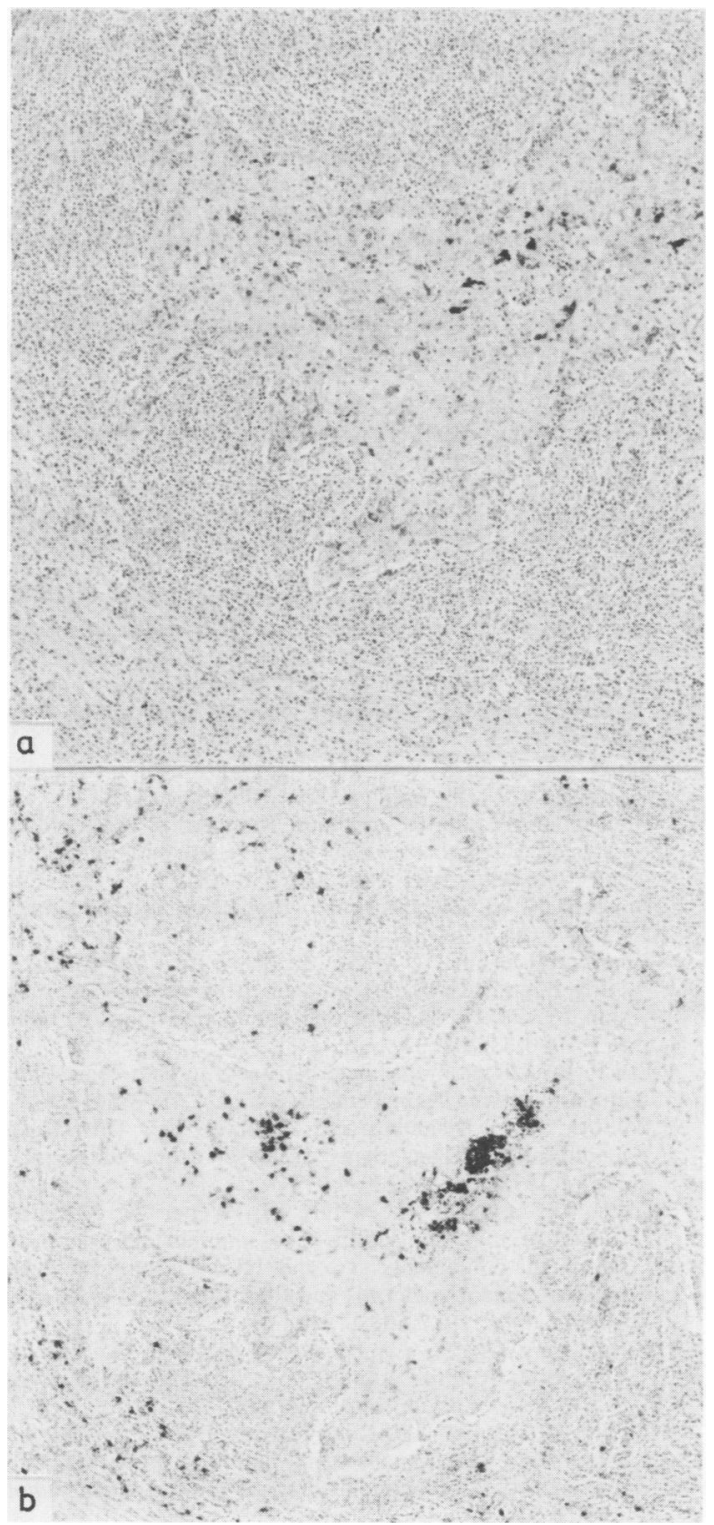

Fig. 4 Serial sections of undifferentiated nasopharyngeal carcinoma metastatic to lymph node treated with anti-S-100 (a) or antimuramidase antiserum (b). S-100 labelled cells are confined to the neoplastic epithelial nest; muramidase labelled cells are present in both the epithelial nest and surrounding lymphoid tissue. Haematoxylin counterstain. $\times 100$.

dendritic shaped S-100 containing cells. No S-100 labelled cells were seen in squamous cell carcinomas of the oral cavity or larynx (Fig. 3).

When serial sections of nasopharyngeal car- cinoma were treated with antimuramidase antiserum, a population of rounded cells, mainly polymorphonuclear and monocytes, was shown in both neoplastic and accompanying lymphoid tissue. By morphological and topographical criteria, however, it was apparent that S-100 labelled cells did not react with the antimuramidase antiserum (Fig. 4).

In previous studies ${ }^{13-15}$ antikeratin antiserum confirmed the epithelial nature of all cases of undifferentiated nasopharyngeal carcinoma examined by giving focal staining in many of the neoplastic cells. No preferential relation between S-100 labelled cells and either keratin labelled or unlabelled anaplastic epithelial cells could be ascertained.

\section{Discussion}

In this study S-100 immunostaining allowed us to detect in undifferentiated nasopharyngeal carcinoma an appreciable number of labelled cells characterised by dendritic shape and irregularly indented nuclei. These cells can be identified by morphological and immunohistochemical criteria as belonging to the Langerhans' or the interdigitating reticulum cell types, which are currently considered to be closely related cells with the special function of antigen presentation. ${ }^{16-18}$ In fact, both epidermal Langerhans' and interdigitating reticulum cells of human lymphoid organs have been shown to be stained by anti-S-100 antisera. ${ }^{91012}$ The finding in undifferentiated nasopharyngeal carcinoma of S-100 labelled cells with features of Langerhans' and of interdigitating reticulum cells, both in primary tumour and in lymph node metastases and occasionally in the surrounding lymphoid infiltrate, seems to suggest a traffic of these cells in the neoplastic environment. In this respect, migration of Langerhans' cells or their bone marrow precursors into the epidermis ${ }^{1719}$ and their movement from epidermis to dermis and subsequent appearance in dermal lymphatics and draining lymph nodes after antigen challenge ${ }^{20}$ have been shown in normal skin. An increased number of Langerhans' cells has been reported in benign epidermal tumours, whereas contradictory findings of the presence and the number of Langerhans' cells have been reported in squamous cell carcinomas both of cutaneous and mucosal origin..$^{21-25}$ In our study, S-100 labelled dendritic cells appeared to be few or absent in most squamous cell carcinomas of both mucosal and epidermal origin.

The finding of an appreciable number of cells resembling Langerhans' or interdigitating reticulum cells in most cases of undifferentiated nasopharyngeal carcinoma is particularly important 
because of the involvement of the immune system in the control of Epstein-Barr virus infection and Epstein-Barr virus associated neoplasms, including undifferentiated nasopharyngeal carcinoma. ${ }^{5}$ Further studies, also supported by immunoultrastructural investigations, are needed to ascertain the precise nature of these cells and their possible role in the modulation of anti-Epstein-Barr virus immune responses and host-tumour interactions.

This work was supported in part by a grant from Progetto Finalizzato "Oncologia" of the CNR. The authors thank Mr Alessandro Rinelli for his excellent technical assistance and Mr Paolo Baldassari for his editorial assistance.

\section{References}

' Andersson-Anvret M, Forsby N, Klein G, Henle W. Relationship between the Epstein-Barr virus and undifferentiated nasopharyngeal carcinoma: correlated nucleic acid hybridization and histopathological examination. Int $J$ Cancer 1977;20:286-94.

${ }^{2}$ Klein G. The relationship of the virus to nasopharyngeal carcinoma. In: Epstein MA, Achong BG, eds. The Epstein-Barr virus. Berlin: Springer Verlag, 1979:339-50.

${ }^{3}$ Micheau C, de The' G, Orofiamma B, et al. Practical value of classifying NPC in two major microscopical types. In: Grundmann E, Krueger GRF, Ablashi DV, eds. Nasopharyngeal carcinoma. Stuttgart: Gustav Fisher Verlag, 1981:51-7.

${ }^{4}$ Karpinsky A, Krueger GRF, Wustrow J, Hass W, Ablashi DV, Pearson GR. Epstein-Barr virus antibody titres in various histological types of carcinoma in the nasopharynx. In: Grundmann E, Krueger GRF, Albashi DV, eds. Nasopharyngeal carcinoma. Stuttgart: Gustav Fisher Verlag, 1981:95-110.

${ }^{s}$ Epstein MA, Morgan AJ. Clinical consequences of Epstein-Barr virus infection and possible control by anti-viral vaccine. Clin Exp Immunol 1983;53:257-71.

- Jondal M, Klein G. Classification of lymphocytes in nasopharyngeal carcinoma (NPC) biopsies. Biomedicine 1975;23: 163-5.

${ }^{7}$ Konorza G, Sesterhenn K, Krueger GRF, Ablashi DV. Distribution of T- and B-cells and of immunoglobulin producing cells in tumor tissue of patients with nasopharyngeal carcinoma. $J$ Cancer Res Oncol 1979;93:195-204.

${ }^{8}$ Wustrow J, Karpinski A, Haas W, Krueger GRF, Bertram G, Sesterhenn K. Correlation of histological NPC tumor types with local and perripheral T- and B-cell values. In: Grundmann E, Krueger GRF, Albashi DV, eds. Nasopharyngeal carcinoma. Stuttgart: Gustav Fisher Verlag, 1981:193-9.

' Cocchia D, Michetti F, Donato R. Immunochemical and immunocytochemical localization of $\mathbf{S 1 0 0}$ antigen in normal human skin. Nature 1981;294:85-7.

${ }^{10}$ Takahashi K, Yamaguchi H, Ishizechi J, Nakajima T, Nakazato
J. Immunohistochemical and immunoelecton microscopic localization of S-100 protein in the interdigitating reticulum cells of human lymph node. Virchows Arch (Cell Pathol) 1981;37:125-35.

" Sternberger LA, Hardy PH, Cuculis JJ, Meyer HG. The unlabelled antibody enzyme method of immunochemistry. Preparation and properties of soluble antigen-antibody complex (horseradish peroxidase-antihorseradish peroxidase) and its use in identification of spirochetes. J Histochem Cytochem 1970; 18:315-33.

${ }^{12}$ Lauriola L, Michetti F, Stolfi VM, Tallini G, Cocchia D. Detection by $\mathrm{S}-100$ immunolabelling of interdigitating reticulum cells in human thymomas. Virchows Arch (Cell Pathol) 1984; 45: 187-95.

${ }^{13}$ Madri JA, Barwick KW. An immunohistochemical study of nasopharyngeal neoplasms using keratin antibodies. Am J Surg Pathol 1982;6:143-9.

${ }^{14}$ Miettinen M, Lehto V-P, Virtanen I. Nasopharyngeal lymphoepithelioma. Histological diagnosis as aided by immunohistochemical demonstration of keratin. Virchows Arch (Cell Pathol) 1982;40:163-9.

is Gusterson BA, Mitchell DP, Warburton MJ, Carter RL. Epithelial markers in the diagnosis of nasopharyngeal carcinoma: an immunocytochemical study. J Clin Pathol 1983;36:628-31.

16 Veldman JE. Histophysiology and electron microscopy of the immune response. Dijkstra Niemeyer, Groningen. Acad Thesis. 1970.

${ }^{17}$ Stingl G, Tamaki K, Katz SI. Origin and function of epidermal Langerhans' cells. Immunol Rev 1980;53:149-74.

${ }^{18}$ Hoefsmit ECM, Duijvestijn AM, Kamperdijk EWA. Relation between Langerhans cells, veiled cells, and interdigitating cells. Immunobiology 1982;161:255-65.

${ }^{19}$ Breathnach AS. Electron micrographs from a collection. Clin Exp Dermatol 1977;2:1-16.

${ }^{20}$ Silberberg-Sinakin I, Gigli I, Baer RL, Thorbecke GJ. Langerhans cells: role in contact hypersensitivity and relationship to lymphoid dendritic cells and to macrophages. Immunol $\operatorname{Rev}$ 1980;53:203-32.

${ }^{21}$ Lisi P. Investigation on Langerhans cells in pathological human epidermis. Acta Derm Venereol (Stockh) 1973;53:425-8.

${ }^{22}$ Wilborn WH, Dismukes DE, Montes LF. Ultrastructural identification of Langerhans cells in seborrheic keratosis. J Cut Pathol 1978;5:368-72.

${ }^{23}$ Loning T, Caselitz J, Seifert G, Weber K, Osborn M. Identification of Langerhans cells: simultaneous use of sera to intermediate filaments, T6 and HLA-Dr antigens on oral mucosa, human epidermis and their tumours. Virchows Arch (Pathol Anat) 1982;398:119-28.

${ }^{24}$ Fernandez-Bussy R, Cambazard F, Mauduit G, Schmitt D, Thivolet $J$. $T$ cell subsets and Langerhans cells in skin tumours. Eur J Cancer Clin Oncol 1983;19:907-13.

${ }^{25}$ Gatter KC, Morris HB, Roach B, Mortimer P, Fleming KA, Mason DY. Langerhans' cells and $T$ cells in human skin tumours: and immunohistological study. Histopathology 1984;8:229-44.

Requests for reprints to: Dr Libero Lauriola, Department of Human Pathology, Universita Cattolica, Largo Francesco Vito, 1, 00168 Roma, Italy. 